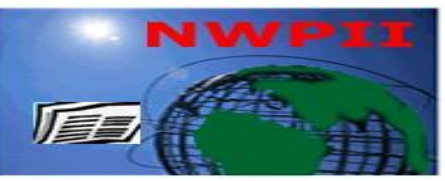

American Journal of Biomedical Sciences

ISSN: 1937-9080

nwpii.com/ajbms

\title{
Prevalence of Asymtomatic Bacteriuria among Pregnant Women Attending Antenatal in Port Harcourt Township, Nigeria and Antibiogram of Isolated Bacteria
}

\author{
Smart Enoch Amala ${ }^{1}$, Easter Godwin Nwokah ${ }^{1}$ \\ ${ }^{1}$ Department of Medical Laboratory Science, Rivers State University of Science and Technology, Nkpolu \\ Oroworukwo, Port Harcourt, Nigeria. \\ ${ }^{+}$Corresponding Author \\ Amala, Smart E. \\ Department of Medical Laboratory Science \\ Rivers State University of Science and Technology \\ Nkpolu Oroworukwo \\ Port Harcourt, Nigeria \\ E-mail: smart.amala@yahoo.com
}

Received: 8 April 2015; | Revised: 1 June 2015; | Accepted: 20 June 2015

\begin{abstract}
The prevalence of asymptomatic bacteriuria among 330 pregnant women attending antenatal at two hospitals in Port Harcourt, Rivers State, Nigeria, was investigated by urine culture. One hundred (100) nonpregnant women were screened as control. The percentage prevalence of bacteriuria among the pregnant women was $13.6 \%$, while the percentage prevalence among non-pregnant women was $11.1 \%$. The prevalence among pregnant women attending antenatal hospital 1, $\mathrm{CHC}$ was $13.8 \%$, whereas those attending hospital 2, BMSH was $13.5 \%$. The prevalence of bacteriuria by trimesters were: $1^{\text {st }}$ trimester $17.9 \%, 2^{\text {nd }}$ trimester $12.5 \%$ and $3^{\text {rd }}$ trimester $14.5 \%$. The prevalence of bacteriuria among the pregnant women by age groups were, 16-20yrs $13.5 \%, 21-25 y r s 14.4 \%$, 26-30yrs $14.1 \%$, 31-35yrs $12.0 \%$ and 36-40yrs $8.0 \%$. The percentage occurrences of isolated bacteria from urines of pregnant women were: Escherichia coli 28.9\%, Staphylococci 20.0\%, Streptococci 15.6\%, Proteus spp. 8.9\%, Klebsiella spp. 8.9\%, Enterobacter 6.7\%, Enterococcus $8.9 \%$ and Pseudomonas aeruginosa 2.2\%. The percentage occurrences of isolated bacteria from the urines non-pregnant women (control) were: Escherichia coli 27.2\%, Staphylococci spp. 18.1\%, Streptococci $9.1 \%$, Proteus spp. $18.1 \%$, klebsiella $18.1 \%$ and Pseudomonas $9.1 \%$. From the results obtained, Escherichia coli were the most prevalent bacterium isolated from the urines of pregnant and non-pregnant women. Statistical analysis at $\mathrm{P}<0.05$ did not show age as a predisposing factor to bacteriuria in pregnancy. Asymptomatic bacteriuria is common among antenatal patients, therefore all pregnant women should screened during their first visit by urine culture to detect and treat overt UTI to avoid complications that may ensue in both mother and fetus. Antibiotics susceptibility testing against isolates showed that, both Gram negative bacilli and Gram positive cocci isolated were resistant to the first line antibiotics.
\end{abstract}




\section{Introduction}

Asymptomatic bacteriuria is common among women and increases in prevalence with sexual activity, short urethra, pregnancy and easy contamination of the urethra with faecal flora (Girishbabu et al., 2011).Asymptomatic bacteriuria is confirmed with positive culture of bacteria containing more than $10^{5} \mathrm{cfu} / \mathrm{ml}$ of clean catch, mid stream urine (MSU) of a patient without symptoms of urinary tract infection (UTI) Jepsen et al.,(1982). Urine has significant bacteriuria when bacteria count from fresh, clean catch urine exceeds $10^{5} \mathrm{cfu} / \mathrm{ml}$ of urine (Gammeguard et al., 2004). Urinary tract infection is the second most common type of bacterial infection in man (Jepson et al., 2006). UTI may affect any part of urinary tract e.g. urethra (urethritis), bladder (cystitis), kidney (pylonephritis), etc. Urinary tract infections account for approximately $10 \%$ visit by women and $15 \%$ by pregnant women to the clinicians. The prevalence of urinary tract infection had been found to be $8 \%$ (Hultgreen, 2007). Kerure et al.,(2013) observed that the prevalence of bacteriuria in pregnancy may rise between 2 $10 \%$. Other studies in India had reported prevalence as high as $8 \%$ (Balamurugan et al., (2012). The prevalence of asymptomatic bacteriuria has previously been reported to be 213\% (Masinde et at., 2009). The reasons are, increased rate of urine formation during pregnancy as a result of increase load of secretory products, the rate of glomerular filtration which may increase up to $50 \%$ or more in pregnancy, progesterone and relaxation hormone secreted during pregnancy, these have direct effect on the relaxation of the ureter and renal pelvis with marked decrease in urethral peristalsis. Contamination of the female urethra is enhanced by sexual intercourse pressure which can introduce bacteria into the bladder consequently, coupled with honeymoon cystitis. The use of contraceptives, diaphragm and spermatocides alters the normal flora of introitus causing colonization by Escherichia coli and other bacteria thereby predisposing to bacteriuria (Stamm et al., 2007). E. coli is responsible for more than $80 \%$ of all community acquired UTI. Others bacteria were: Proteus spp, Pseudomonas spp, Klesiella, Staphylococci, etc. The relative high prevalence of asymptomatic bacteriuria during pregnancy and the consequences on women and their pregnancies justify screening of pregnant women for bacteriuria to avoid the squeals with treatment (Balamurugan et al., 2012, Patel et al., 2015). Urine culture remains the gold standard method for screening asymptomatic bacteriuria during pregnancy (Gayathree et al., 2010).

This study is designed to determine the prevalence of asymtomatic bacteriuria among pregnant women, trimester prevalence of bacteriuria, prevalence among age groups, the percentage occurrences of isolated bacteria and antibiogram of the isolated bacteria.

\section{Materials and Methods}

\subsection{Study areas}

The samples were obtained from pregnant women attending antenatal clinic in Braithwaite Memorial Specialist Hospital (BMSH) which is one of the referral hospitals in Port Harcourt Metropolis and Church Hill Clinic (CHC), subsequently referred to as $\mathrm{BMSH}$ and $\mathrm{CHC}$ respectively. Both are government hospitals located in Port Harcourt Township, the capital of Rivers State, Nigeria. The hospitals are chosen to enable us obtain the required sample size from volunteers.

\subsection{Collection of urine samples}

Mid-stream, clean-catch urine samples were obtained from 330 pregnant women attending antenatal clinics in both BMSH and CHC. The samples were collected, irrespective of trimester of pregnancy. Sterile wide mouth containers were given to the subjects on arrival at the hospital, who were instructed on how to collect their urine specimen without contamination. The urine specimens were taken to the laboratory for immediate analysis and where delay was 
envisaged, they were preserved in refrigerator at $4^{0} \mathrm{C}$. One hundred (100) urine samples from nonpregnant women were also collected from volunteers as control as control.

\subsection{Preparation of media}

All media were prepared according to the manufacturer's instructions.

\subsection{Cultivation of samples}

Each urine sample was inoculated and streaked out on cystine lactose electrolyte deficient agar (CLED) and Colombia blood agar using a standard wire-loop calibrated to deliver $0.002 \mathrm{ml}$ of urine. CLED plates were incubated aerobically, while Colombia blood agar plates were incubated in $\mathrm{CO}_{2}$ atmosphere; both at $37^{\circ} \mathrm{C}$ for 18-24 hours. Significant bacteriuria was expressed as $10^{5} \mathrm{cfu} / \mathrm{ml}$ of urine. The results of urinalysis and microscopy were used to correlate with culture results.

\subsection{Identification of Isolates and Susceptibility Testing}

Isolates were identified following standard microbiological protocols including Gram stain, carbohydrate metabolisms, indole test, motility test, oxidase test, urease test, catalase test, citrate test, DNAase test, litmus milk decolourization test, coagulase test (Criuckshank, et al., 2006; Cheesbrough, 2002; Cowan \& Steel, 2008). Kirby-Bauer disc diffusion method on Muller Hinton agar plate was used as recommended by (NLSI/ NCCLS, 2012). The antibiotics tested against isolated bacteria were: ofloxacin, kanamycin, carbanicillin, ciproxin, nalidixic acid, ampicillin, gentamacin, chloramphenicol. penicilliin, streptomycin, obenin, erythromycin, tetracycline.

\subsection{Exclusion criteria}

Women excluded were: (a) The women with history of antibiotic therapy for past two weeks, (b) Women with underlying diabetes mellitus (c) Pyrexia.

\subsection{Statistical analysis}

Statistical analysis was done using statistical package for social science (SPSS) version 20.

\section{Results}

The overall percentage prevalence of bacteriuria among pregnant women attending antenatal in $\mathrm{BMSH}$ and $\mathrm{CHC}$ was $13.6 \%$, while the prevalence rate of bacteriuria among pregnant women attending $\mathrm{BMSH}$ are $13.8 \%$, and $13.5 \%$ for $\mathrm{CHC}$ respectively. The prevalence of bacteriuria among non-pregnant women used as control was $11.1 \%$. The prevalence rate of bacteriuria among pregnant women was higher by $2.5 \%$ (as shown in table 1 ).

Table1. Percentage Prevalence of bacteriuria among pregnant and non-pregnant women

\begin{tabular}{|l|l|l|}
\hline Hospital & $\begin{array}{l}\text { Number } \\
\text { sampled }\end{array}$ & $\begin{array}{l}\text { Number } \\
\text { positive }\end{array}$ \\
\hline CHC & 130 & $18(13.9 \%)$ \\
\hline BMSH & 200 & $27(13.5 \%)$ \\
\hline $\begin{array}{l}\text { Total pregnant } \\
\text { women }\end{array}$ & 330 & $45(13.6 \%)$ \\
\hline $\begin{array}{l}\text { Non pregnant } \\
\text { women }\end{array}$ & 100 & $11(11.1 \%)$ \\
\hline
\end{tabular}

Number in parenthesis $=$ percentages

The percentage of subjects by trimester were $1^{\text {st }}$ trimester $28(8.84 \%), 2^{\text {nd }} 192(58.18 \%)$ and $3^{\text {rd }} 110(33.33 \%)$ respectively. The overall prevalence of bacteriuria by trimester were $1^{\text {st }}$ trimester $5(17.9 \%), 2^{\text {nd }}$ trimester $24(12.5 \%)$ and $3^{\text {rd }}$ trimester $16(14.5 \%)$ respectively.

The prevalence by trimesters from each hospital was $\mathrm{CHC} 1^{\text {st }}$ trimester $16,3(18.8 \%), 2^{\text {nd }}$ trimester $74,9(12.2 \%)$ and $3^{\text {rd }}$ trimester $40,16(14.5 \%)$ respectively.

In BMSH, $1^{\text {st }}$ trimester $12,2(16.6 \%) ; 2^{\text {nd }}$ trimester, $118,15(12.7 \%)$; and $3^{\text {rd }}$ trimester 70 , $10(14.3 \%$ ) respectively (as shown in table 2 ).

The pregnant women used for this study were between ages 16 and 40 years. They were grouped into 5 groups at 5 years (yrs) interval. The prevalence of bacteriuria among the pregnant women by age group were:

Ages 16 - 20 yrs 62, 9(14.5\%), ages 21 - 26 yrs $139,20(14.4 \%)$ ages $26-30$ yrs 85, 12(14.1\%), 25 subjects from the ages $31-35$ yrs $25,3(12.0 \%)$ and ages 36 - 40 yrs 19, 1(8.0\%) respectively. The prevalence of bacteriuria among pregnant women was high from ages 16 - 35 yrs. (Table 3). 
Table 2: Prevalence of bacteriuria by trimester among pregnant women

\begin{tabular}{|l|l|l|l|l|l|l|}
\hline Trimester & \multicolumn{2}{|c|}{ CHC } & \multicolumn{2}{c|}{ BMSH } & \multicolumn{2}{c|}{ CHC/BMSH } \\
\hline & $\begin{array}{l}\text { Number } \\
\text { sample }\end{array}$ & $\begin{array}{l}\text { Number } \\
\text { positive }\end{array}$ & $\begin{array}{l}\text { Number } \\
\text { sampled }\end{array}$ & $\begin{array}{l}\text { Number } \\
\text { Positive }\end{array}$ & $\begin{array}{l}\text { Number } \\
\text { Sampled }\end{array}$ & $\begin{array}{l}\text { Number } \\
\text { Positive }\end{array}$ \\
\hline First & 16 & $3(18.8)$ & 12 & $2(16.7)$ & 28 & $5(17.9)$ \\
\hline Second & 74 & $9(12.2)$ & 118 & $15(12.7)$ & 192 & $24(12.5)$ \\
\hline Third & 40 & $6(15.0)$ & 70 & $10(14.3)$ & 110 & $16(14.6)$ \\
\hline Total & 130 & $18(13.9)$ & 200 & $27(13.5)$ & 330 & $45(13.6)$ \\
\hline
\end{tabular}

Numbers in parenthesis $=$ percentages

Table 3: Age prevalence of bacteriuria among pregnant and non- pregnant women(control)

\begin{tabular}{|l|l|l|l|l|}
\hline $\begin{array}{l}\text { Age group } \\
\text { (years) }\end{array}$ & Pregnant women & Number positive & $\begin{array}{l}\text { Non pregnant } \\
\text { women }\end{array}$ & Number positive \\
\hline $16-20$ & 62 & $9(14.5)$ & 16 & $2(12.5)$ \\
\hline $21-25$ & 139 & $20(14.4)$ & 28 & $4(14.2)$ \\
\hline $26-30$ & 85 & $12(14.1)$ & 24 & $3(12.5)$ \\
\hline $31-35$ & 19 & $3(12.0)$ & 17 & $2(11.8)$ \\
\hline $36-40$ & 19 & $1(8.0)$ & 9 & $0(0.0)$ \\
\hline Total & 330 & $45(13.6)$ & 100 & $11(11.0)$ \\
\hline
\end{tabular}

Numbers in parenthesis =percentages

Table 4: Percentage occurrences of isolated bacteria from the urines of pregnant and non pregnant women(control)

\begin{tabular}{|l|l|l|l|l|}
\hline Isolated bacteria & $\begin{array}{l}\mathrm{BMSH} \\
\text { \% occurrences }\end{array}$ & $\begin{array}{l}\mathrm{CHC} \\
\text { \% occurrences }\end{array}$ & $\begin{array}{l}\text { BMSH/CHC } \\
\text { \% occurrences }\end{array}$ & $\begin{array}{l}\text { Nonpregnant women } \\
\text { \% occurrences }\end{array}$ \\
\hline E.coli & $8(29.6)$ & $5(27.8)$ & $13(28.9)$ & $3(27.3)$ \\
\hline Staphylococci spp. & $5(18.5)$ & $4(22.2)$ & $9(20.0)$ & $2(18.2)$ \\
\hline Streptococci spp. & $4(14.8)$ & $3(16.7)$ & $7(15.6)$ & $1(9.1)$ \\
\hline Proteus spp. & $3(11.1)$ & $1(5.6)$ & $4(8.9)$ & $2(18.2)$ \\
\hline Klebsiella spp. & $2(7.4)$ & $2(11.1)$ & $4(8.9)$ & $2(18.2)$ \\
\hline Enterobacter spp. & $2(7.4)$ & $1(5.6)$ & $3(6.7)$ & $0(0.00)$ \\
\hline $\begin{array}{l}\text { Enterococcus } \\
\text { faecalis }\end{array}$ & $2(.4)$ & $2(11.1)$ & $4(8.9)$ & $0(0.00)$ \\
\hline Pseudomonas spp. & $1(3.70)$ & $0(0.00)$ & $1(2.2)$ & $1(9.1)$ \\
\hline Total & 27 & 18 & 45 & 11 \\
\hline
\end{tabular}

Numbers in parenthesis $=$ percentages

The overall percentage occurrences of isolated bacteria from the urines of pregnant women were: Escherichia coli 13(28.9\%), Staphylococci spp. $9(20.0 \%), \quad$ Streptococci 7(15.6\%), Enterococcus 4(8.89\%), Proteus spp. 4(8.9\%), Enterobacter spp. 3(6.7\%), klebsiella spp. 4(8.9\%) and Pseudomonas aeruginosa $1(2.2 \%)$ respectively.

The percentage occurrences of isolated bacteria from each hospital are: BMSH, E. coli 5(29.6\%), Staphylococci spp. 4(18.5\%) Streptococci spp. 3(14.8\%), Enterococcus faecalis 2(7.2\%) and Pseudomonas 0(0.00\%) Enterobacter 2(7.4\%), Proteus spp. 3(11.1\%),
Klebsiella spp. 2(7.4\%) respectively; whereas CHC, E. coli 5(27.8\%), Staphylococci spp. 4(22.2\%), Streptococci spp. 3(16.7\%), Proteus spp. 1(5.6\%), Klebsiella spp. 2(11.1\%), Enterococcus faecalis 2(11.1\%) and Pseudomonas $1(0.00 \%)$ respectively.

From the results, E. coli was the most predominant bacteria isolated from the urines of pregnant and non-pregnant women (Table 4).

The results of antibiotic susceptibility testing of isolated bacteria were: Ofloxacin $100 \%$, Ciprofloxacin 100\%, Gentamacin 81.2\%, Nalidixic acid $75.0 \%$, Kanamycin $56.3 \%$, Chloramphenicol $37.5 \%$, Carbenicillin $0.00 \%$ and 
Ampicillin $0.00 \%$; for the Gram positive bacteria, whereas, for the Gram positive cocci, Gentamacin $81.87 \%$, Eryrhromycin $72.7 \%$, Chloraphenicol 36.4\%, Streptomycin 36.4\%, Tetracycline $36.4 \%$, Obenin $0.00 \%$ and Penicillin $0.00 \%$ respectively.

\section{Discussion}

From the results, $8.84 \%$ pregnant women attended antenatal in the $1^{\text {st, }}$ trimester, this delay may have aided the establishment of some overt bacteriuria in the $2^{\text {nd }}$ and $3^{\text {rd }}$ trimesters. If they had reported early, most asymptomatic cases may have been detected and treated in $1^{\text {st }}$ trimester and the prevalence observed in $2^{\text {nd }}$ and $3^{\text {rd }}$ trimesters would have dropped. Various workers examining the prevalence of bacteriuria among pregnant women had reported varing percentage prevalence rates of bacteriuria. It had been observed that the prevalence of bacteriuria among non-pregnant women was from $8-10 \%$ and the percentage prevalence rate among pregnant women could be as high as $15 \%$ (Kass, 1998) In this study, the percentage prevalence of bacteriuria among pregnant women was $13.6 \%$. Asymptomatic bacteriuria quoted in literatures varies from 2-10\% (Enayat et al., 2008, Kerure et al., 2013). Masinde et al., (2009) observed prevalence of $2-13 \%$ in Tanzania. In a study conducted in West Bengal, a prevalence of $11 \%$ among pregnant women was recorded (Rajshkehar \& Umashanker, 2013). In Bangladeshi, prevalence of $12 \%$ was obtained (Ullah, et al., 2007) and 7.3\% in Kumasi, Ghana (Turpin et al., 2007). In Yobe State, Nigeria, (Musbau \& Muhammed, 2013) observed a prevalence of $43.3 \%$ and $55.0 \%$ by (Bankole et $a l ., 2015)$. The prevalence rate observed in this study was within ranges obtained by other workers. The difference in prevalences could be attributed to difference in socioeconomic status and healthcare development (Taiwo et al., 2009). Kass, (1998) observed that pregnancy may not predispose to bacteriuria but to the bacteriuric women, it is an added burden. Kunin, (1970), also noted that about $50 \%$ of women with previously diagnosed bacteriuria develop UTI within three months of marriage or regular sexual intercourse. Abbey, (1987) also noted that previous experience of urinary tract infection predisposes to bacteriuria. In this study, the difference in the prevalence of bacteriuria among pregnant and non-pregnant women (control) was $2.5 \%$. Factors that may predispose to bacteriuria in pregnancy includes: increased rate of urine formation during pregnancy as a result of increased load of secretory products, 50\% increase in glomerular filtration, progesterone and relaxing hormones secreted during pregnancy which have direct effects on the relaxation of the ureter and pelvis, coupled with marked decrease in urethral peristalsis and stasis (Girishbabu et al., 2011, Kenure et al., 2013, Imade et al., 2010, Turpin et al., 2007). Statistical analysis at $\mathrm{p}<0.05$ did not show significant difference in the prevalence rate of bacteriuria among pregnant and non-pregnant women. The percentage prevalence of bacteriuria by age groups among pregnant women from the age 16-35 years were high. This was in line with the findings of (Rajshekhar \& Umashenkar, 2013) that most positive cases of bacteriuria in pregnancy were within the above age groups. The prevalence rate of bacteriuria in women rises with age and sexual activities (Santiago et al; 1980; Kunin \& Degroot, 1975). The association between overt bacteriuria and sexual activities in young married women is well known, that the term "honey moon cystitis" is used to describe the entity; however, infection does not subside at this stage; but rather becomes an important complication in pregnancy (Kunin, 1972; Ellis, 2007). Sexual activities may aid increase prevalence of bacteriuria observed among women from ages 16-35 years, since sexual pressure introduces bacteria from vagina into the urethra, aided by the burden of pregnancy.

The pregnant women screened were 330, $16(4.84 \%)$ were in the first trimester and the prevalence was $17.9 \%$. Registration of pregnant women to antenatal clinic early in $1^{\text {st }}$ trimester is necessary to detect and treat underlying asymptomatic bacteriuria to avoid complications later in pregnancy. High prevalence of bacteriuria observed in the first trimester could be as a result of underling asymptomatic urinary infection before pregnancy ensued or at unset of pregnancy 
due to changes associated with it. Asymptomatic bacteriuria in pregnancy may cause complications such as pylonephritis, hypertensive disease of pregnancy, anemia, chronic renal failure, premature delivery and foetal mortality (Foxman ,2002, Msbau and Muhammad, 2013).

Several groups of bacteria have been implicated in UTI, the most common group were the Enterobacteriaceae and most commonly reported bacteria among this group is E. coli, accounting for over $80 \%$ of isolated bacteria (Kerure et al., 2013; Chandel et al., 2012, Kass, 2002). Sujatha \& Manju, (2014) found E. coli was $61 \%$ of isolated bacteria among pregnant women in Kupur, India.

Abu-bakarer \& Oyaide (1982), reported that E. coli accounted for $25 \%$ of isolated bacteria, whereas (Akinkugbe et al., 1973) found E. coli was $23 \%$, (Turpin et al., 2007) recorded $E$, coli as 37\%, (Musbau \& Muhammad, 2013) recorded $E$. coli $36.9 \%$ of isolated bacteria among pregnant women and (Oyeyipo \& Onorlode 2014) observed E. coli to be 53\%. In this study, E. coli accounted for $28.8 \%$ of isolated bacteria among pregnant women and $27.2 \%$ among the non-pregnant women (control group).

This finding is in agreement with the findings of other workers that $E$. coli is the most predominant bacteria isolated from bacteriuric women. E. coli is the most predominant aerobic bacteria in human intestine, the proximity of the female genital tract and anal region aids easy transfer of $E$. coli to the vagina and easy transport to the urethra by sexual pressure during sexual intercourse. Engaging in both anal and vaginal sex in tandem is likely to aid contamination of the vagina with $E$. coli for onward transmission to the urethra. Urinary stasis is common in pregnancy and since $E$. coli prefers such environment, they utilize the opportunity to cause UTI. Staphylococci species are the second most prevalent bacteria 20\%. Staphylococci are carried by humans as normal microbiota on the skin, hands, nostril etc. Conditions .that causes depletion of Lactobacillus acidophilus in the vagina usually encourages the establishment of Staphylococci and other bacteria. The percentage occurrence of Staphylococci reported by (Ekwempu et al; 1981) was 20\%, whereas
(Musbau \& Muhammad, 2013) reported 22\% occurrence. The percentage Streptococci from this was $15.5 \%$ of isolated bacteria.

Islam, (1981) quantitatively cultured specimen from vulva and vagina swabs of antenatal women, the isolates from the sites were similar with overall carriage rate of $21 \%$ Streptococci. Wood and Dillon, (1981) in a study of bacteriuria in pregnancy reported 14 isolates of group B-Streptococci which was (30.4\%) of isolated bacteria. In Benin City, Nigeria, (Bankole et al., 2015), had 22.5\% of Streptococci. The shows that the percentage occurrence of Streptococci might vary in different population. The frequent implication of Streptococci in bacteriuria may be due to their persistent presence in female genital tract, since the anatomy favours their existence in the environment (Victoria \& Mark, 2012). The common source of the recalcitrant and opportunistic bacterium $P$. aeruginosa in UTI is the environments, the organism is widely distributed in soil, water, sewage, plants and animal surfaces. It is associated with biofilm formation (catheter) which are resistant to antimicrobial agents as well as host defense mechanism (Ravi et al., 2009). Due to this reason, Pseudomonas aeruginosa is of concern to treating physicians. Most bacteria associated with asymptomatic bacteriuria in this study, were bacteria suspected to cause female infertilities in cases where they had been isolated from the cervix of females suffering from unexplained infertility (Vijay et al., 2011). The antibiotics effective against urinary pathogens (Gram negative bacilli) were: ofloxacin, ciproxacin, gentamacin and nalidixic acid. Gentamacin is known to be nephrotoxic, but can be used when necessary. The Gram negative positive are susceptible to gentamicin and erythromycin. This result was similar to that of (Oyeyipo and Onorlode, 2013) in UPTH, Port Harcourt. Both groups of bacteria are resistant to the first line antibiotics.

\section{Conclusion}

The prevalence of bacteriuria among pregnant women obtained and the trimester 
prevalence are within the rage observed by other workers. The pregnant women within age groups from 16-35 yrs had high prevalence of bacteriuria (the ages of active sexual activities), this may be coupled with the influence of pregnancy. E. coli was the most predominant bacteria isolated from urines of pregnant and non-pregnant women. Isolated bacteria were resistant to first line antibiotics.

\section{References}

1. Abbey, S. D. (1987), Asymtomatic bacteriuria in Port metropolis, Nigeria. Microbios, 49, $73-77$.

2. Abu - Bakare, A. and Oyaide, S. M. (1982) Asymptomatic bacteriuria in Nigerian school girls. Journal of Tropical Medicine and Hygiene, 85, 95 -97.

3. Akinloye, O. Ogbulo, D.O., Akinloye, O.M. \& Terry Alli, O.A.(2006). Asymptomatic bacteriuria of pregnancy in Ibadan, Nigeria: a reassessment. British Journal of Biomedical Science, 63, 109-112.

4. Balamungan, S., Chaitanya, S., Jayapreye., S., Priyadarshini, S., Jeya, S. \& Ramesh, R.K. (2012). Reagent strip testing for asmptomatic bacteriuria in pregnant women. A cost effective screening tool in under resourced setting. Journal of Clinical Development Research 6, 671-673.

5. Chandel, 1.R., Kanga, A., Thakur, K. et al.(2012). Prevalence of pregnancy associated bacteriuria. A study done in tertiary care hospital. The Journal of Obstetrics and Gynecology India, 62(5), 511-514. DOI: 10.1007/s13224-011-0071-2

6. Cheesbrough, M. (2002).District Laboratory Practice in tropical countries. Part2, Cambridge University press, Madrid, Spain.

7. Criuckshank, R., Duguid, J. p., Marmiom, D. P. \& Swain, P. (2006). Medical
Microbiology $12^{\text {th }}$ edition, Churchill living stone, Edinburgh.

8. Cowan, S. T. \& Steel, K. J. (2008). Microbiological methods. $3^{\text {rd }}$ edition, Bult University, park press.

9. Ekwempu, C. C., Lawande, R. V. \& Ehber, L. J. (1981). Microbial flora of the lower genital tract of women in labour in Zaria, Nigeria. Journal of clinical pathology, 34, 82 - 83. DOI: $10.1136 /$ jcp.34.1.82

10. Ellis, A. k. \& Verma, S. (2000). Quality of life in women with urinary tract infection in female. Journal of American Board Family Practice, 13, 392 - 397.

11. Enayat, K., Fariba, F. \& Bahram, N. (2008). Asyptomatic bacteriuria among pregnant women referred to our outpatient clinic in Sanandaj, Iran. International Brazilian Journal of Urology, 34(6) 699-707. DOI: $10.1590 /$ S1677-55382008000600004

12. Foxman, B. (2002). Epidemiology of urinary tact infections, morbidity and economic cost. American Journal of Medicine, 113(1A), 5S13S. DOI: 10.1016/S0002-9343(02)01054-9

13. Gaaythree, I., Shetty, S.. Deshpande, S.R. \& Venkatesh, D.T. (2010). Screening for asymptomatic bacteriuria in pregnancy. An evaluation of various screening testsin Hassan District Hospital, India. Journal of Clinical Disease Research, 4(4) 2702-2706.

14. Girishbuabu, R.J., Srikrishna, R. \& Ramesh, S.T.(2011). Asymptomatic bacteriuria in pregnancy (2011). International Joournal of Biology \& Medical Research, 2(3), 740-742.

15. Hooton,T. M., Scholes, D. \& Stapleton, A. E. (2000). A prospective study of asymptomatic bacteriuria in sexually active young women. New England Journal of Medicine, 335(7), $468-47$. DOI: $10.1056 /$ NEJM199608153350703

16. Islam, A.K.N.S. (1981). Primary carrier site of group B Streptococci in pregnant women correlated with serotype distribution and maternal parity. Journal of Clinical Pathology, 34, 778-781.

DOI: $10.1136 /$ jcp.34.1.78

17. Imade, P.E., Izekor, P.E.. Eghafona, N.O., Enabuele, A.I. \& Ophori, E. (2010). Asymptomatic bacteriuria among pregnant 
women. North American Journal of Medical Science, 2(6), 263-266.

18. Jepsen, O. B.; Oleganlarsen, S., Dascher, J. Cronrooc, P., meers, P. D., Nystrom, B., Rotter, M. \& Sander, J. (1982). Urinary tract infection and bacteriuria in hospitalized medical patients. Journal of Hospital Infection, 3, $241-251$.

DOI: 10.1016/0195-6701(82)90043-3

19. Kass, E. H. (2002). Bacteria and diagnosis of infections of the urinary tract. Archives of internal medicine, 100, $709-712$.

DOI: 10.1001/archinte.1957.00260110025004

20. Kerure, S.B., Surpur, R., Sagarad, S.S., \& Hegadi , S. (2013). Aymptomatic bacteriuria among pregnant women. International Journal of Contraceptives Obstetric and Gynecology, 2, 213-216.

DOI: $10.5455 / 2320-1770 . i j \operatorname{rcog} 20130621$

21. Kunin, C. M. (1970). The natural history of recurrent bacteriuria in school girls. New England Journal of Medicine, 282, 1443 14447.

DOI: 10.1056/NEJM197006252822601

22. Masinde, A., Gumodoka, B., Kilonzo, A. \& Mshana, S.E.(2009),Prevalence of urinary tract infection among pregnant women at Bugando Medical Centre mwaanza,Tanzania. Tanzania Journal of Medical Research, 11(3), 154-159.

23. Musbau, S. \& Muhammad, Y. (2013).Prevalence of bacteriuria among pregnant women attending clinic at Federal Medical Centr Nguru Yobe State. Scholars Journal of Applied Medical Science, 1(5), 658-660.

24. Oyeyipo, O. O. \& Onorlode, o. (2013). Assessment of asymptomatic bacteriuria in pregnant women in Port Harcourt, South Southern Nigeria. Research Gate, 5(1) 6772.

25. Performance Standard of Antimicrobial Disc Susceptibility Tests (2012). Approval Standard $11^{\text {th }}$ Ed. MO2-32(1). National Committee for Clinical Laboratory Standards, Wayne, PA, USA.

26. Patel, H.D., Levsey, S.A., Swann, R.A. \& Bukhari, S.S. (2005). Can urine deepstick testing for urinary tract infection at the pion of cure the laboratory work load, Journal of Clinical Pathology, 951-954.

DOI: $10.1136 /$ jcp.2004.025429

27. Rajshekhar, D.K. \& Umashanker,(2013). Prevalence of asymptomatic bacteriuria among pregnant women in tertiary care hospital. International Journal of Scientific and Research Publication, 5(11), 1-4.

28. Ravi, k., Sanjay C \& Kusum H. (2009). Comparative study clinical and environmental isolates of Pseudomonas aeruginosa in terms of quorum sensing, outer membrane proteins and their ability to cause UTI, American Journal of Biomedical Sciences, 1(3),205-214.

29. Stamm, W. E. \& Hooton, J. M. (2002). Management of urinary tract infections in adults. New England Journal of Medicine, 329, $1328-1330$.

30. Stamm, W. E. \& Hooton, J. M. (2006). Urinary tract infection: from pathogenesis to treatment. Scientific American Journal of medicine, 1, 15 - 19.

31. Sujatha, N. \& Manju, N, (2014). Journal of Clinical and Diagnostic Reseaarch, 8(4), 13.

32. Taiwo S.S., Adegbite I.I. \& Adefioye, A.O. (2009). Asymptomatic bacteriuria in pregnancy in Oshiogbo with special reference to Staphylococcus saprophiticus. African Jounal of Infectious Diseases, 3(2),36-43.

33. Turpin C,A., Bridget M., Dokogo, K.A.,\& Frimpong E.H.92007). Asymptomatic bacteriura in pregnant women attending antenatal clinic at Komfo Teaching Hospital, Kumasi, Ghana. Ghana Medical Journal, 41(1), 26-29.

34. Ullah, A.M., Barman, A., Siddique, M.A. \& Haque, A.K.M.(2007). Prevalence of asymptomatic bacteriuria and consequencies in pregnancy in a rural community of Bangladesh. Bangladesh Medical Research Council Bulletin, 33; 60-64.

35. Victoria, M.A. and Mark, H.Y.(2012). Management of group B Streptococcal bacteriuria in pregnancy. Obstetrician and Gynaecologist, 276, 452-456. 
36. Vijay, P., Aanan, T. D. \& Siftjit, K. (2011). Bacteriological study of the cervix of females suffering from unexplained infertility. American Journal of Biomedical Sciences, 3(2), $84-89$.
37. Wood, E.G. and Dillon, H.D. (Jr.) (1981). Streptococcal bacteriuria in pregnancy. American Journal of Obstetrics and Gynecology, 140(5), 515-520. 